Article

\title{
In Situ Growth Behavior of SiC Whiskers with High Aspect Ratio in the Synthesis of $\mathrm{ZrB}_{2}-\mathrm{SiC}$ Composite Powders
}

\author{
Xiaoqing Lian *, Xiaohu Hua, Xiaogang Wang and Lirong Deng \\ School of Materials Science and Engineering, Xi'an University of Science and Technology, Xi'an 710054, China; \\ huaxiaohu@xust.edu.cn (X.H.); wangxiaogang@xust.edu.cn (X.W.); denglirong@xust.edu.cn (L.D.) \\ * Correspondence: lianxiaoqing@xust.edu.cn
}

Received: 6 July 2020; Accepted: 29 July 2020; Published: 8 August 2020

check for updates

\begin{abstract}
Aiming to provide key materials in order to improve the fracture toughness of $\mathrm{ZrB}_{2}$ ceramics, $\mathrm{ZrB}_{2}-\mathrm{SiC}$ composite powders with in situ grown $\mathrm{SiC}$ whiskers were successfully synthesized via a simple molten-salt-assisted ferrous-catalyzed carbothermal reduction method. Thermodynamic calculations on the $\mathrm{ZrO}_{2}-\mathrm{SiO}_{2}-\mathrm{B}_{2} \mathrm{O}_{3}-\mathrm{C}-\mathrm{Fe}$ system were carried out. The effects of heating temperature and ferrous catalyst amount on the growth behavior of $\mathrm{SiC}$ whiskers in $\mathrm{ZrB}_{2}-\mathrm{SiC}$ composite powders were investigated using X-ray diffraction (XRD), scanning electron microscopy (SEM), X-ray energy dispersive spectroscopy (EDS), and transmission electron microscopy (TEM). The results showed that the aspect ratio of $\mathrm{SiC}$ whiskers and the relative content of $\mathrm{ZrB}_{2}$ particles increased with increasing heating temperature (1523-1723 K) and a molar ratio of $\mathrm{Fe}$ to $\mathrm{ZrSiO}_{4}$ from 0:1 to 0.2:1. Phase-pure $\mathrm{ZrB}_{2}$-SiC composite powders were obtained at $1723 \mathrm{~K}$ when the molar ratio of raw materials was 0.2:0.5:1:1.5:8.4 (Fe: $\mathrm{NaCl}: \mathrm{ZrSiO}_{4}: \mathrm{B}_{2} \mathrm{O}_{3}: \mathrm{C}$ ). Single crystalline $\beta$-SiC whiskers with a mean diameter of $0.15 \mu \mathrm{m}$ and an aspect ratio of 70-120 were homogeneously distributed in the final composite powders. A molten-salt-assisted iron-catalyzed vapor-solid mechanism was promoted for the growth mechanism of in situ grown $\mathrm{SiC}$ whiskers.
\end{abstract}

Keywords: in situ synthesis; whisker; $\mathrm{SiC} ; \mathrm{ZrB}_{2}$

\section{Introduction}

Owing to their unique advantages including low density, high melting point, and stable chemical properties, $\mathrm{ZrB}_{2}$ ultrahigh-temperature ceramics are promising materials for leading edges and propulsion components of hypersonic aerospace vehicles and advanced reusable atmospheric reentry vehicles [1-3]. However, they suffer from difficult densification, poor oxidation resistance, and low fracture toughness [4]. Incorporating $\mathrm{SiC}$ whiskers into the $\mathrm{ZrB}_{2}$ ceramic matrix was found to be effective in improving these performances, especially for fracture toughness [5-7]. For example, fracture toughness of monolithic $\mathrm{ZrB}_{2}$ ceramics was commonly only 3-4 MPa.m ${ }^{1 / 2}$ [8], while that increased to above $5 \mathrm{MPa} \cdot \mathrm{m}^{1 / 2}$ through a bridging toughening mechanism if $20 \mathrm{vol} \% \mathrm{SiC}$ whiskers were added [6]. However, except for the inevitable grinding damage, it was sometimes difficult to obtain the uniform dispersion of $\mathrm{SiC}$ whiskers, which limited the improvement of the performance of $\mathrm{ZrB}_{2}-\mathrm{SiC}$ composite ceramics. An effective way to overcome the problems is to synthesize $\mathrm{ZrB}_{2}-\mathrm{SiC}$ composite powders with in situ grown $\mathrm{SiC}$ whiskers.

$\mathrm{ZrB}_{2}$-SiC composite powders have been synthesized through various approaches [9-14]. Xie [10] synthesized spherical $\mathrm{ZrB}_{2}-\mathrm{SiC}$ composite powders ranging from $100 \mathrm{~nm}$ to $300 \mathrm{~nm}$ through a one-step reduction process of $\mathrm{ZrO}_{2}, \mathrm{~B}_{4} \mathrm{C}$, carbon black, and silicon. $\mathrm{Li}$ [11] prepared $\mathrm{ZrB}_{2}-\mathrm{SiC}$ composite powders by molten-salt-mediated reduction of $\mathrm{ZrSiO}_{4}, \mathrm{~B}_{2} \mathrm{O}_{3}$, activated carbon, and $\mathrm{Mg}$, 
which exhibited grain sizes of several microns and comprised $\mathrm{SiC}$ nanoparticles well distributed in the $\mathrm{ZrB}_{2}$ matrix. $\mathrm{ZrB}_{2}$-SiC composite powders were synthesized by Cao [12] via a combined sol-gel and microwave boro/carbothermal reduction process using zirconium oxychloride, boric acid, tetraethoxysilane, and glucose as starting materials; the resulting crystalline sizes of $\mathrm{ZrB}_{2}$ and SiC were about 58 and $27 \mathrm{~nm}$, respectively. The as-prepared powders thus obtained were with isometric morphology. Some studies on anisotropic $\mathrm{ZrB}_{2}-\mathrm{SiC}$ composite powders were reported in recent years. Lin [15] prepared $\mathrm{ZrB}_{2}-\mathrm{SiC}$ composite powders with in situ rod-shaped $\mathrm{ZrB}_{2}$. As-prepared $\mathrm{ZrB}_{2}-\mathrm{SiC}$ composite powders were modified by Zhong [16] using in situ grown $\mathrm{SiC}$ nanowires with a diameter of $200 \mathrm{~nm}$. However, studies on the preparation of $\mathrm{ZrB}_{2}-\mathrm{SiC}$ composite powders with in situ grown $\mathrm{SiC}$ whiskers have not been as widely reported.

$\mathrm{SiC}$ whiskers or nanowires were commonly prepared by molten-salt-assisted (using $\mathrm{NaCl}, \mathrm{KCl}$, or $\mathrm{NaF}$ ) [17] or transition-metal-catalyzed (using ferrous, cobalt, or nickel) carbothermal reduction of silicon dioxide $\left(\mathrm{SiO}_{2}\right)$ [18]. In this work, a simple molten-salt-assisted iron-catalyzed carbothermal reduction method was employed to synthesize $\mathrm{ZrB}_{2}$-SiC composite powders with in situ grown $\mathrm{SiC}$ whiskers using zircon, boron oxide, carbon black, ferrous powders, and $\mathrm{NaCl}$ as raw materials. Aiming to obtain $\mathrm{SiC}$ whiskers with ideal morphology (straight shape, small diameter, high aspect ratio, etc.) and clarify their in situ growth behavior in $\mathrm{ZrB}_{2}-\mathrm{SiC}$ composite powders, based on the thermodynamic calculations on the $\mathrm{ZrO}_{2}-\mathrm{SiO}_{2}-\mathrm{B}_{2} \mathrm{O}_{3}-\mathrm{C}-\mathrm{Fe}$ system, the effects of heating temperature and ferrous catalyst amount on the phase and microstructure of as-prepared powders, especially on the morphology evolution of $\mathrm{SiC}$ whiskers were investigated. Further, growth mechanisms of in situ grown $\mathrm{SiC}$ whiskers were investigated. This work may serve as a theoretical basis for the preparation of anisotropic $\mathrm{ZrB}_{2}-\mathrm{SiC}$ composite powders.

\section{Materials and Methods}

Commercially available powders of zircon $\left(\mathrm{ZrSiO}_{4}, 97.20 \%, \sim 14.3 \mu \mathrm{m}\right.$, Chenyuan Powder, Zibo, Shandong, China), boron oxide $\left(\mathrm{B}_{2} \mathrm{O}_{3}, 99.9999 \%, \sim 2.2 \mu \mathrm{m}\right.$, Xingye Metal, Xingtai, Hebei, China), carbon black (C, 99.50\%, 3.6 $\mu \mathrm{m}$, Meidi Family, Shanghai, China), ferrous metal s (Fe, 99.9999\%, $\sim 0.2 \mu \mathrm{m}$, Chengxin Metal, Qinghe, Hebei, China), and $\mathrm{NaCl}(99.50 \%, \sim 3.6 \mu \mathrm{m}$, Guoyao Chemical, Shanghai, China) were used as raw materials to synthesize $\mathrm{ZrB}_{2}-\mathrm{SiC}$ composite powders according to the following reaction:

$$
\mathrm{ZrSiO}_{4}(\mathrm{~s})+\mathrm{B}_{2} \mathrm{O}_{3}(\mathrm{l})+7 \mathrm{C}(\mathrm{s})=\mathrm{ZrB}_{2}(\mathrm{~s})+\mathrm{SiC}(\mathrm{s})+7 \mathrm{CO}(\mathrm{g})
$$

Molar ratios of raw materials are listed in Table 1. Excess boron oxide and carbon black were employed with a molar ratio of $1: 1.5: 8.4\left(\mathrm{ZrSiO}_{4}: \mathrm{B}_{2} \mathrm{O}_{3}: \mathrm{C}\right)$. A small amount of $\mathrm{NaCl}$ was added with a molar ratio of $0.5: 1\left(\mathrm{NaCl}: \mathrm{ZrSiO}_{4}\right)$. Samples with different ferrous catalyst amounts with molar ratios of 0:1, 0.1:1, 0.2:1, 0.3:1, and 0.4:1 $\left(\mathrm{Fe}: \mathrm{ZrSiO}_{4}\right)$ were designed, and the corresponding products were referred to as ZS0, ZS1, ZS2, ZS3, and ZS4.

Table 1. Molar ratios of raw materials.

\begin{tabular}{cccccc}
\hline \multirow{2}{*}{ Sample No. } & \multicolumn{5}{c}{ Molar Ratios of Raw Materials } \\
\cline { 2 - 6 } & ZrSiO $_{\mathbf{4}}$ & $\mathbf{B}_{\mathbf{2}} \mathbf{O}_{\mathbf{3}}$ & $\mathbf{C}$ & $\mathbf{F e}$ & $\mathbf{N a C l}$ \\
\hline ZS0 & 1 & 1.5 & 8.4 & 0 & 0.5 \\
ZS1 & 1 & 1.5 & 8.4 & 0.1 & 0.5 \\
ZS2 & 1 & 1.5 & 8.4 & 0.2 & 0.5 \\
ZS3 & 1 & 1.5 & 8.4 & 0.3 & 0.5 \\
ZS4 & 1 & 1.5 & 8.4 & 0.4 & 0.5 \\
\hline
\end{tabular}

After dry mixing for $2 \mathrm{~h}$, the mixed powders were put into a corundum crucible and heated at temperatures ranging from 1573 to $1773 \mathrm{~K}$ for $3 \mathrm{~h}$ under flowing argon gas $(99.999 \%, 0.5 \mathrm{~L} / \mathrm{min}$ ) in 
a box atmosphere furnace. The heating rate was $10 \mathrm{~K} / \mathrm{min}$. The as-prepared powders were washed repeatedly with hot distilled water to remove residual salt and dried at $383 \mathrm{~K}$ for $24 \mathrm{~h}$.

Thermodynamic calculations on the $\mathrm{ZrO}_{2}-\mathrm{SiO}_{2}-\mathrm{B}_{2} \mathrm{O}_{3}-\mathrm{C}$-Fe system were performed using the Enthalpy-Entropy-Heat Capacity (HSC) Chemistry 6.0 software. The phase composition was characterized by X-ray diffraction (XRD, Shimadzu XRD-7000, Kyoto, Japan) with Cu- $\mathrm{K}_{\alpha 1}$ radiation $(\lambda=0.154 \mathrm{~nm})$ at a scan rate of $5^{\circ}(2 \theta) / \mathrm{min}$. The relative contents of crystalline phase were calculated by HighScore Plus software. Scanning electron microscopy (SEM, JSM-6390A, Kyoto, Japan) along with X-ray energy-dispersive spectroscopy (EDS) were used to analyze the morphology of composite powders and assist in phase identification, respectively. Transmission electron microscopy (TEM, JEM-2100, Kyoto, Japan) along with high-resolution transmission electron microscopy (HRTEM) and selected area electron diffraction (SAED) were used to analyze the morphology of SiC whiskers.

\section{Results and Discussion}

\subsection{Thermodynamic Calculation}

Thermodynamic calculation of the $\mathrm{ZrO}_{2}-\mathrm{SiO}_{2}-\mathrm{B}_{2} \mathrm{O}_{3}-\mathrm{C}$-Fe system was performed to predict the reaction production at different temperatures. It is known that pure $\mathrm{ZrSiO}_{4}$ starts decomposing into monoclinic $\mathrm{ZrO}_{2}\left(m-\mathrm{ZrO}_{2}\right)$ and amorphous $\mathrm{SiO}_{2}$ at a temperature above $1725 \mathrm{~K}$ [19]; however, this temperature may be practically lower because of the existence of $\mathrm{NaCl}$ molten salt and liquid $\mathrm{B}_{2} \mathrm{O}_{3}$ and the formation of low-temperature eutectic melts from impurities of zircon [20].

Main possible reactions in this work and their Gibbs free energies $\left(\Delta_{r} G\right)$ at a temperature range of 1000-2000 K are presented in Table 2. Standard Gibbs free energies $\left(\Delta_{r} G^{\theta}\right)$ of Reactions (2)-(6) at different temperatures were calculated using the HSC Chemistry 6.0 software, and CO partial pressure $\left(p_{c o}\right)$ was estimated to be equal to standard atmospheric pressure $\left(p^{\theta}\right)$ during the reaction process under flowing argon gas; thus, the corresponding Gibbs free energy $\left(\Delta_{r} G\right)$ results were obtained, as shown in Figure 1. Setting the Gibbs free energy to be zero, it was calculated that Reactions (2)-(6) could occur at 1776, 1793,1940,1503, and $1588 \mathrm{~K}$, respectively, leading to the appearance of new phases $\mathrm{ZrB}_{2}, \mathrm{SiC}, \mathrm{ZrC}, \mathrm{Fe}_{2} \mathrm{~B}$, and $\mathrm{FeB}$, respectively.

$$
\begin{gathered}
\mathrm{ZrO}_{2}(\mathrm{~s})+\mathrm{B}_{2} \mathrm{O}_{3}(\mathrm{l})+5 \mathrm{C}(\mathrm{s})=\mathrm{ZrB}_{2}(\mathrm{~s})+5 \mathrm{CO}(\mathrm{g}) \\
\mathrm{SiO}_{2}(\mathrm{~s})+3 \mathrm{C}(\mathrm{s})=\mathrm{SiC}(\mathrm{s})+2 \mathrm{CO}(\mathrm{g}) \\
\mathrm{ZrO}_{2}(\mathrm{~s})+3 \mathrm{C}(\mathrm{s})=\mathrm{ZrC}(\mathrm{s})+2 \mathrm{CO}(\mathrm{g}) \\
4 \mathrm{Fe}(\mathrm{l})+\mathrm{B}_{2} \mathrm{O}_{3}(\mathrm{l})+3 \mathrm{C}(\mathrm{s})=2 \mathrm{Fe}_{2} \mathrm{~B}(\mathrm{~s})+3 \mathrm{CO}(\mathrm{g}) \\
2 \mathrm{Fe}(\mathrm{l})+\mathrm{B}_{2} \mathrm{O}_{3}(\mathrm{l})+3 \mathrm{C}(\mathrm{s})=2 \mathrm{FeB}(\mathrm{s})+3 \mathrm{CO}(\mathrm{g})
\end{gathered}
$$

Table 2. Main possible reactions and their Gibbs free energies $\left(\Delta_{r} G\right)$.

\begin{tabular}{cc}
\hline Reactions & $\Delta_{r} \mathbf{G} / \mathbf{K J} \cdot \mathbf{m o l} \mathbf{l}^{-\mathbf{1}}$ \\
\hline$(2)$ & $\Delta_{r} G_{2}=\Delta_{r} G_{2}^{\theta}+5 R T \ln \frac{p_{c o}}{p^{\theta}}\left(\Delta_{r} G_{2}^{\theta}=-170 \sim 621\right)$ \\
$(3)$ & $\Delta_{r} G_{3}=\Delta_{r} G_{3}^{\theta}+2 R T \ln \frac{p_{c o}}{p^{\theta}}\left(\Delta_{r} G_{3}^{\theta}=-67 \sim 266\right)$ \\
$(4)$ & $\Delta_{r} G_{4}=\Delta_{r} G_{4}^{\theta}+2 R T \ln \frac{p_{c o}}{p^{\theta}}\left(\Delta_{r} G_{4}^{\theta}=-19 \sim 322\right)$ \\
$(5)$ & $\Delta_{r} G_{5}=\Delta_{r} G_{5}^{\theta}+3 R T \ln \frac{p_{c o}}{p^{\theta}}\left(\Delta_{r} G_{5}^{\theta}=-191 \sim 207\right)$ \\
$(6)$ & $\Delta_{r} G_{6}=\Delta_{r} G_{6}^{\theta}+3 R T \ln \frac{p_{c o}}{p^{\theta}}\left(\Delta_{r} G_{6}^{\theta}=-180 \sim 264\right)$ \\
\hline
\end{tabular}




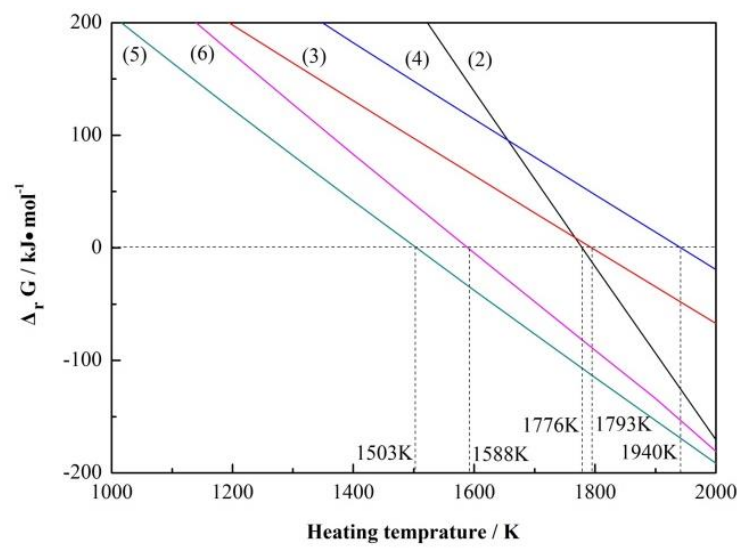

Figure 1. Gibbs free energies $\left(\Delta_{r} G\right)$ of Reactions (2)-(6) at different temperatures.

\subsection{Phase Composition Evolution of Composite Powders}

To determine the lowest heating temperature needed to obtain phase-pure $\mathrm{ZrB}_{2}-\mathrm{SiC}$ composite powders, the XRD patterns and the relative contents of crystalline phase of sample ZS2 heated at temperatures ranging from 1573 to $1773 \mathrm{~K}$ for $3 \mathrm{~h}$ were studied, as shown in Figure 2.

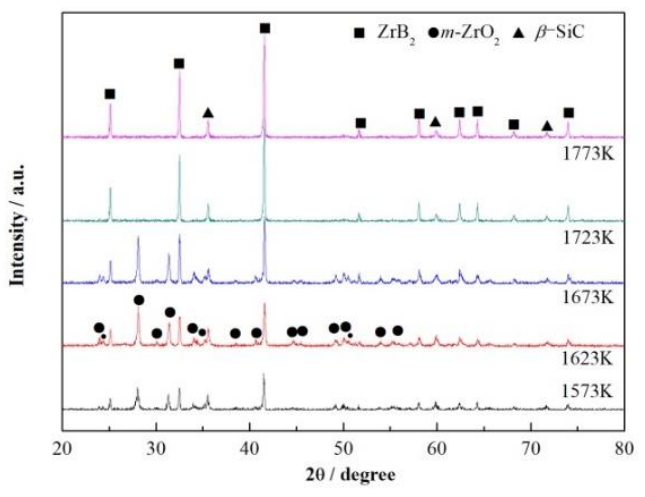

(a)

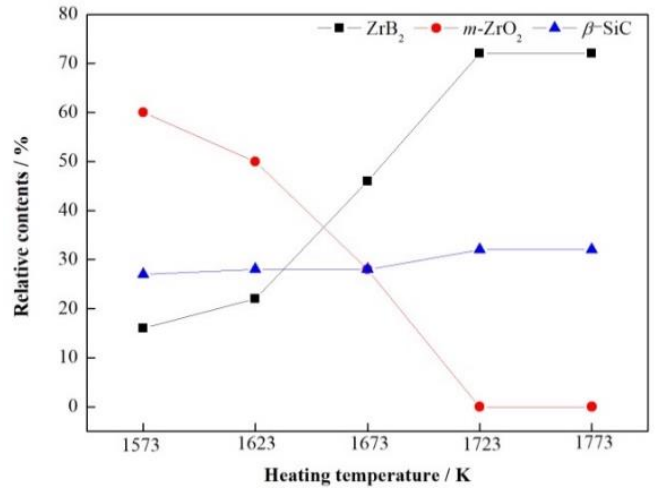

(b)

Figure 2. Phase composition of sample ZS2 heated at 1573-1773 $\mathrm{K}$ for $3 \mathrm{~h}$, $n(\mathrm{Fe}): n(\mathrm{NaCl}): n\left(\mathrm{ZrSiO}_{4}\right): n\left(\mathrm{~B}_{2} \mathrm{O}_{3}\right): n(\mathrm{C})=0.2: 0.5: 1: 1.5: 8.4$. (a) XRD patterns; (b) relative contents of the crystalline phase.

Diffraction peaks of $\mathrm{ZrB}_{2}$ and $\beta$-SiC were observed at $1573 \mathrm{~K}$, while no diffraction peaks of $\mathrm{ZrSiO}_{4}$ were detected (Figure 2a), indicating that $\mathrm{ZrB}_{2}$ and $\beta$-SiC had begun to nucleate and grow before $1573 \mathrm{~K}$ through Reactions (2) and (3), which was much lower than the thermodynamic temperatures of 1776 and $1793 \mathrm{~K}$ as shown in Figure 1. When increasing the temperature from 1573 to $1723 \mathrm{~K}$, $\mathrm{ZrB}_{2}$ content increased continuously from 16 to $72 \%$ (Figure $2 \mathrm{~b}$ ). The slope of the line for Reaction (2) was negative in Figure 1, so increasing the temperature was helpful in forming $\mathrm{ZrB}_{2}$. Meanwhile, $\beta$-SiC content changed little, indicating that formation process of $\beta$-SiC through Reaction (3) had completed at a temperature lower than $1573 \mathrm{~K}$, which was $150 \mathrm{~K}$ lower than that of Zhang [17] via molten-salt-assisted carbothermal reduction with silica fume and phenolic resin as raw materials and close to that of Guo [21] via nickel-catalyzed carbothermal reduction of polycarbosilane (PCS). The relative contents of $\mathrm{ZrB}_{2}$ and $\beta$-SiC showed no obvious changes when further raising the temperature to $1773 \mathrm{~K}$. The weight ratio of $\mathrm{ZrB}_{2}$ to $\beta$-SiC was 72:28 (Figure $2 \mathrm{~b}$ ), which was close to the theoretical value of 74:26 calculated based on Reaction (1), suggesting that phase-pure $\mathrm{ZrB}_{2}$-SiC composite powders were synthesized at $1723 \mathrm{~K}$. This temperature was $50 \mathrm{~K}$ lower than that in the traditional carbothermal reduction of zircon [9]. Therefore, the lowest heating temperature to obtain phase-pure $\mathrm{ZrB}_{2}-\mathrm{SiC}$ composite powders was set as $1723 \mathrm{~K}$. 
Ferrous catalyst amount is another important factor influencing the phase composition of as-prepared composite powders. Figure 3 shows the XRD patterns and the relative contents of crystalline phase of samples ZS0-ZS4 heated at $1723 \mathrm{~K}$ for $3 \mathrm{~h}$. With increasing molar ratio of Fe to $\mathrm{ZrSiO}_{4}, \mathrm{ZrB}_{2}$ peaks were increasingly strong (Figure $3 \mathrm{a}$ ), and its relative contents increased significantly (Figure $3 b$ ). However, the relative contents of $\beta$-SiC changed little (Figure $3 b$ ), indicating that the effects of ferrous catalyst on promoting formation of $\beta-\mathrm{SiC}$ as reported in previous work [22] were negligible at a temperature as high as $1723 \mathrm{~K}$. Hence, phase-pure $\mathrm{ZrB}_{2}-\mathrm{SiC}$ composite powders were synthesized when the molar ratio of $\mathrm{Fe}$ to $\mathrm{ZrSiO}_{4}$ was $0.2: 1$, in which the weight ratio of $\mathrm{ZrB} 2$ to $\beta$-SiC was 72:28 (Figure 3b). Further increasing the molar ratio of $\mathrm{Fe}$ to $\mathrm{ZrSiO}_{4}, \mathrm{ZrC}$ peaks appeared (Figure 3a). Therefore, the optimum molar ratio of raw materials to synthesize phase-pure $\mathrm{ZrB}_{2}-\mathrm{SiC}$ composite powders was 0.2:0.5:1:1.5:8.4 (Fe: $\left.\mathrm{NaCl}: \mathrm{ZrSiO}_{4}: \mathrm{B}_{2} \mathrm{O}_{3}: \mathrm{C}\right)$, i.e., sample ZS2.

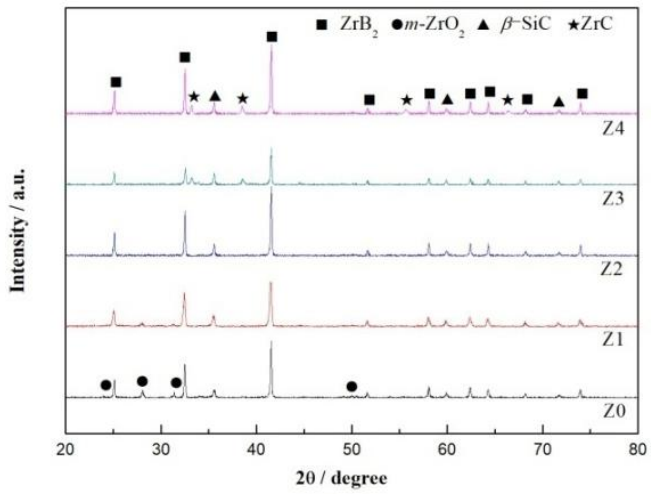

(a)

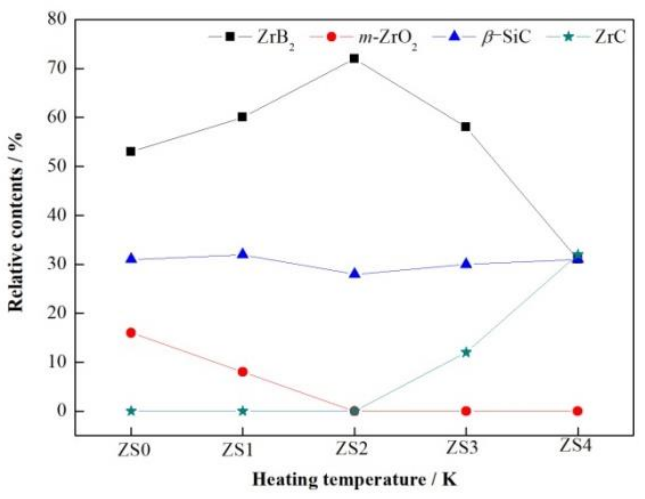

(b)

Figure 3. Phase composition of samples ZS0-ZS4 heated at $1723 \mathrm{~K}$ for $3 \mathrm{~h}, n(\mathrm{Fe}): n\left(\mathrm{ZrSiO}_{4}\right)=0: 1,0.1: 1$, 0.2:1, 0.3:1, and 0.4:1, respectively: (a) XRD patterns; (b) relative contents of the crystalline phase.

\subsection{Microstructure of $\mathrm{ZrB}_{2}$-SiC Composite Powders with In Situ Grown SiC Whiskers}

The microstructure of sample ZS2 heated at $1723 \mathrm{~K}$ for $3 \mathrm{~h}$ was examined using SEM and EDS, as shown in Figure 4.

There are mainly three morphologies shown in Figure 4a, including whiskers with a mean diameter of $0.15 \mu \mathrm{m}$ and aspect ratio of 70-120, tabular grains with a diameter of $4-5 \mu \mathrm{m}$, and nanoparticles with a mean diameter of $0.03 \mu \mathrm{m}$. The EDS spectra at point 001 showed the existence of elements Si and C (Figure $4 \mathrm{~b}$ ), and the EDS spectra at point 002 showed the existence of elements $\mathrm{Zr}$ and B (Figure 4c), so the whiskers were $\mathrm{SiC}$ and tabular grains were $\mathrm{ZrB}_{2}$, which was confirmed by EDS mapping of the $\mathrm{Si}$ element (Figure $4 \mathrm{~d}$ ) and $\mathrm{Zr}$ element (Figure 4e) as well. Meanwhile, it is shown in Figure $4 \mathrm{~d}$ that the nanoparticles in Figure $4 \mathrm{a}$ were $\mathrm{SiC}$. It was seen that $\mathrm{SiC}$ whiskers were homogeneously distributed in the final composite powders.

There were minor spectra of Fe element at typical point 001 , but no spectra of $B$ element were seen, confirming that $\mathrm{Fe}$ element existed as neither $\mathrm{Fe}_{2} \mathrm{~B}$ nor $\mathrm{FeB}$, i.e., Reactions (5) and (6) did not occur owing to some dynamical factors, although thermodynamic temperatures of $\mathrm{Fe}_{2} \mathrm{~B}$ and $\mathrm{FeB}$ (1503 and $1588 \mathrm{~K}$ ) were lower than that of $\mathrm{SiC}(1776 \mathrm{~K})$. Neither $\mathrm{Fe}_{2} \mathrm{~B}$ nor $\mathrm{FeB}$ was found in the $\mathrm{ZrB}_{2}$ whiskers prepared by $\mathrm{Khanr}$ [23] using $\mathrm{ZrO}_{2}, \mathrm{H}_{3} \mathrm{BO}_{3}, \mathrm{C}, \mathrm{NaCl}$, and catalyst $\mathrm{Ni} / \mathrm{Co} / \mathrm{Fe}$ as raw materials, which was consistent with the results of this work. 


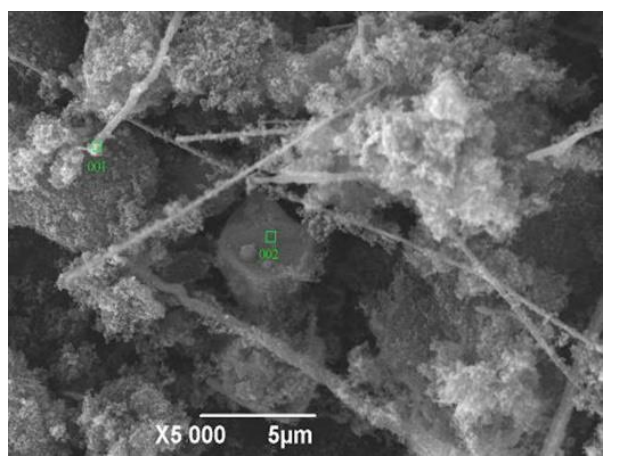

(a)

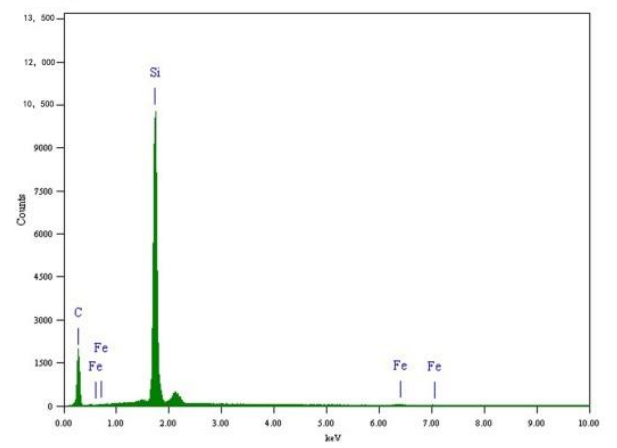

(b)

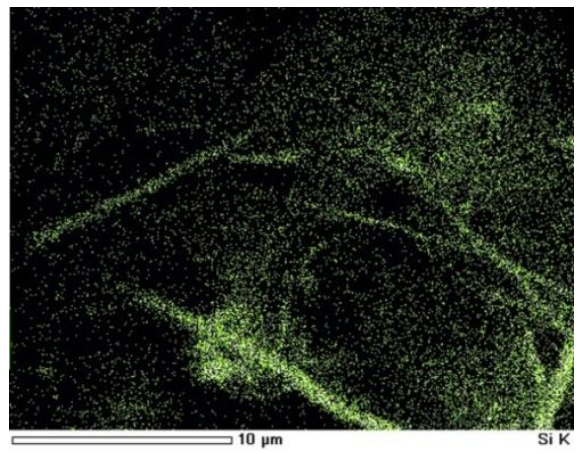

(d)



(c)

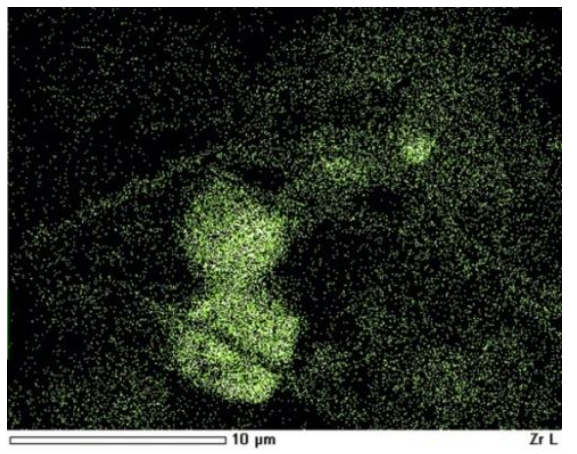

(e)

Figure 4. Microstructure of sample ZS2 heated at $1723 \mathrm{~K}$ for $3 \mathrm{~h}$ : (a) scanning electron microscopy (SEM) image; (b) energy-dispersive spectroscopy (EDS) spectra at point 001; (c) EDS spectra at point 002; (d) EDS mapping of Si element; (e) EDS mapping of Zr element.

The growth direction and crystal structure of $\mathrm{SiC}$ whiskers were further investigated by TEM, HRTEM, and SAED, as seen in Figure 5. The single SiC whisker was smooth and straight with a diameter of about $0.15 \mu \mathrm{m}$ (Figure $5 \mathrm{a}$ ). The lattice space value was measured to be $0.25 \mathrm{~nm}$ (Figure $5 \mathrm{~b}$ ), which was in agreement with the plane distance of the (111) plane [24], the close-packed planes of $\beta$-SiC, and so it was concluded that the whiskers preferentially grew along the $<111>$ direction. The SAED patterns confirmed that the $\mathrm{SiC}$ whisker was single crystalline $\beta$-SiC (3C-SiC). 


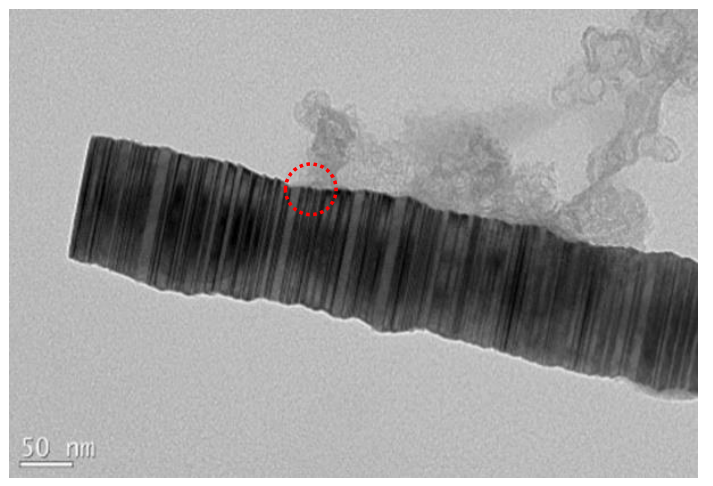

(a)

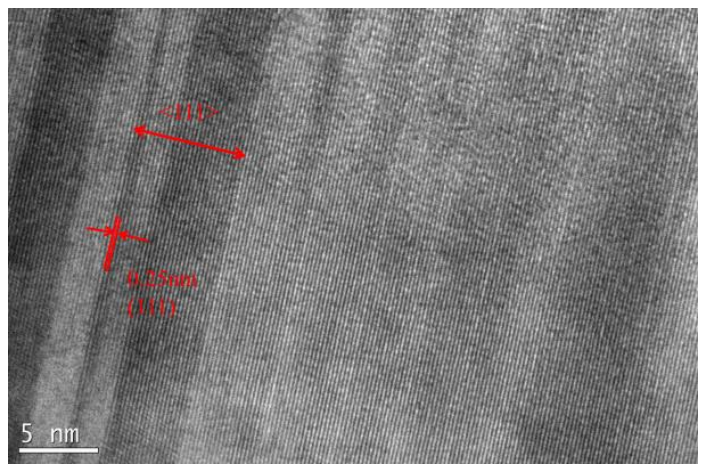

(b)

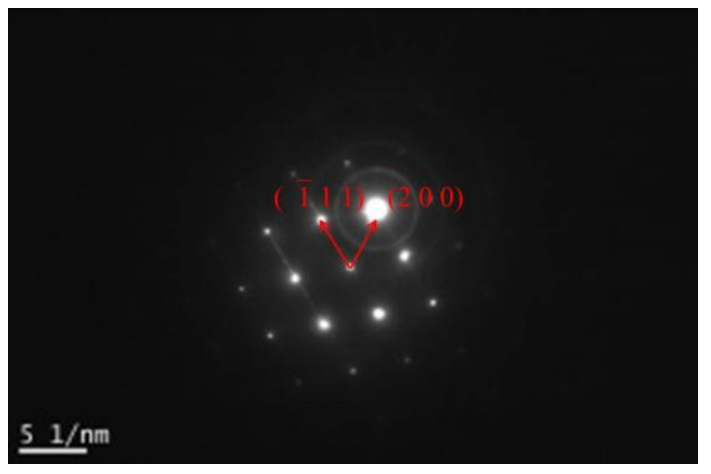

(c)

Figure 5. Microstructure of a single SiC whisker in sample ZS2: (a) transmission electron microscopy (TEM) image; (b) high-resolution transmission electron microscopy (HRTEM image); (c) selected area electron diffraction (SAED) image.

\subsection{Morphology Evolution of SiC Whiskers}

The morphology of $\mathrm{SiC}$ whiskers plays an important role in toughening mechanisms, including crack bridging, crack deflection, and pullout effects [5-7], and thus the morphology evolution of SiC whiskers was studied by comparing the microstructures of samples at different heating temperatures and ferrous catalyst amounts, as shown in Figure 6. Table 3 lists the morphology parameters of SiC whiskers in the composite powders.

Table 3. Morphology parameters of SiC whiskers in samples as shown in Figure 6.

\begin{tabular}{|c|c|c|c|c|c|}
\hline \multirow{2}{*}{ Sample No. } & \multirow{2}{*}{$\mathrm{n}(\mathrm{Fe}): \mathrm{n}\left(\mathrm{ZrSiO}_{4}\right)$} & \multirow{2}{*}{ Temperature/K } & \multicolumn{3}{|c|}{ Morphology Parameters } \\
\hline & & & Shape & Mean Diameter/ $\mu \mathrm{m}$ & Aspect Ratio \\
\hline $\mathrm{Z} 2$ & $0.2: 1$ & $1623 \mathrm{~K}$ & $\begin{array}{l}\text { straight } \\
\text { whisker }\end{array}$ & 0.15 & $20-40$ \\
\hline $\mathrm{Z0}$ & $0: 1$ & $1723 \mathrm{~K}$ & $\begin{array}{l}\text { straight } \\
\text { whisker }\end{array}$ & $0.1-0.3$ & $20-40$ \\
\hline $\mathrm{Z1}$ & $0.1: 1$ & $1723 \mathrm{~K}$ & $\begin{array}{l}\text { straight } \\
\text { whisker }\end{array}$ & 0.15 & $40-50$ \\
\hline $\mathrm{Z2}$ & $0.2: 1$ & $1723 \mathrm{~K}$ & $\begin{array}{l}\text { straight } \\
\text { whisker }\end{array}$ & 0.15 & $70-120$ \\
\hline $\mathrm{Z3}$ & $0.3: 1$ & $1723 \mathrm{~K}$ & bent whisker & 0.3 & $5-10$ \\
\hline $\mathrm{Z} 4$ & $0.4: 1$ & $1723 \mathrm{~K}$ & short rod & 0.3 & $<5$ \\
\hline
\end{tabular}




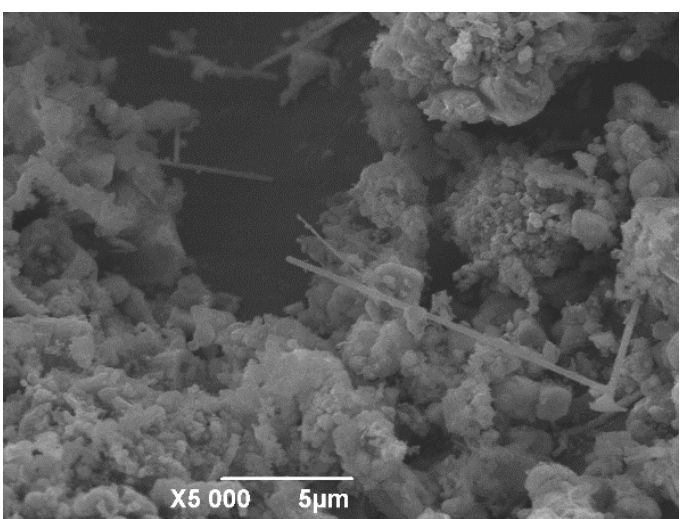

(a)

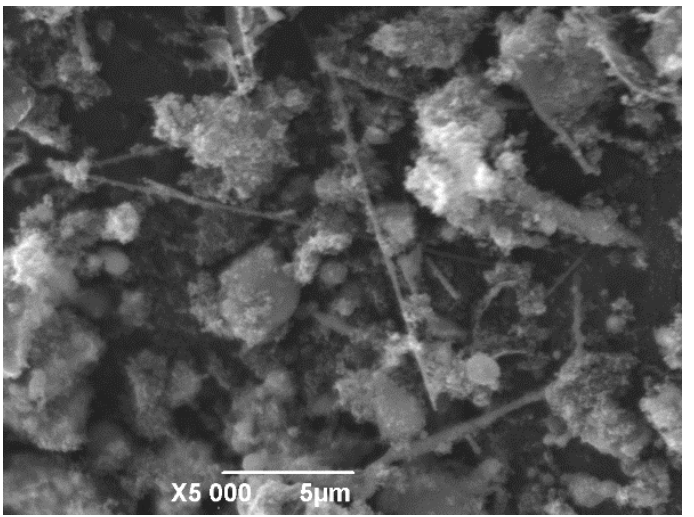

(c)

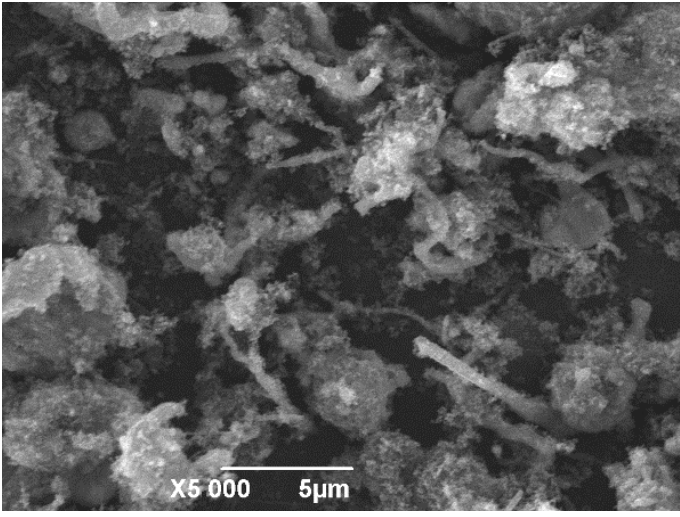

(e)



(b)

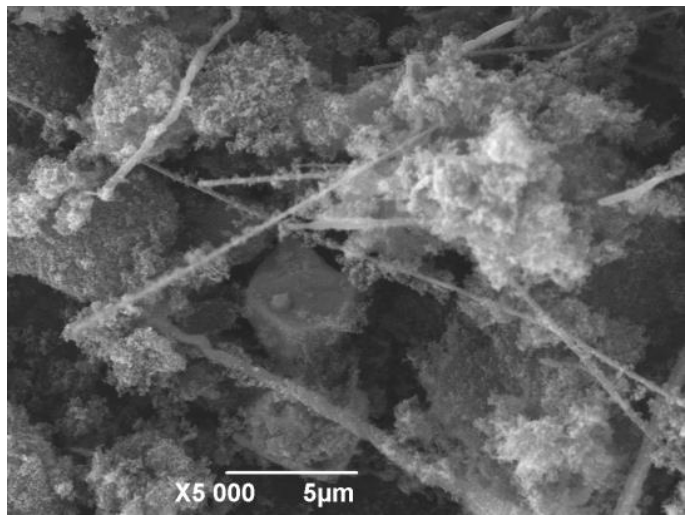

(d)

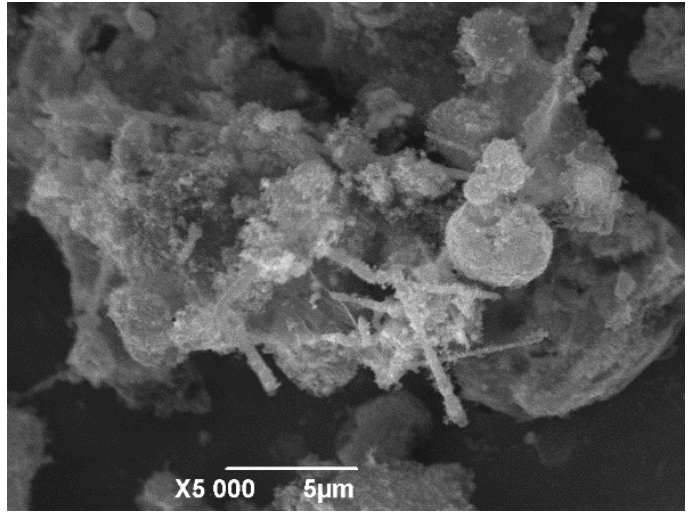

(f)

Figure 6. SEM images of samples at different processing conditions: (a) $1623 \mathrm{~K}, \mathrm{n}(\mathrm{Fe}): \mathrm{n}\left(\mathrm{ZrSiO}_{4}\right)=0.2: 1$; (b) $1723 \mathrm{~K}, \mathrm{n}(\mathrm{Fe}): \mathrm{n}\left(\mathrm{ZrSiO}_{4}\right)=0: 1 ;$ (c) $1723 \mathrm{~K}, \mathrm{n}(\mathrm{Fe}): \mathrm{n}\left(\mathrm{ZrSiO}_{4}\right)=0.1: 1 ;$ (d) $1723 \mathrm{~K}, \mathrm{n}(\mathrm{Fe}): \mathrm{n}\left(\mathrm{ZrSiO}_{4}\right)=0.2: 1$; (e) $1723 \mathrm{~K}, \mathrm{n}(\mathrm{Fe}): \mathrm{n}\left(\mathrm{ZrSiO}_{4}\right)=0.3: 1 ;$ (f) $1723 \mathrm{~K}, \mathrm{n}(\mathrm{Fe}): \mathrm{n}\left(\mathrm{ZrSiO}_{4}\right)=0.4: 1$.

With increasing heating temperature from 1623 to $1723 \mathrm{~K}$ (Figure 6a,d) and increasing molar ratio of $\mathrm{Fe}$ to $\mathrm{ZrSiO}_{4}$ from 0:1 to 0.2:1 (Figure $6 \mathrm{~b}-\mathrm{d}$ ), the aspect ratio of $\mathrm{SiC}$ whiskers increased while the diameter changed little. Since the relative contents of $\beta$-SiC changed little according to XRD analysis in Figure 2; Figure 3, it was concluded that, in the processing conditions above, the dominant growth behavior of $\mathrm{SiC}$ whiskers was one-dimensional growth along $<111>$ rather than nucleation. When the molar ratio of $\mathrm{Fe}$ to $\mathrm{ZrSiO}_{4}$ increased to 0.3:1, the morphology of SiC whiskers changed from straight and fine to bent and coarse. The whiskers made contact with each other under too many catalyst 
droplets, hence they could not grow continuously and evenly. Furthermore, when the molar ratio rose to $0.4: 1$, only a few short rods remained and serious grain agglomeration occurred. Therefore, ideal morphology of $\mathrm{SiC}$ whiskers was obtained when the molar ratio of Fe to $\mathrm{ZrSiO}_{4}$ was $0.2: 1$ and heating temperature was $1723 \mathrm{~K}$, which were the optimum processing conditions for the synthesis of phase-pure $\mathrm{ZrB}_{2}-\mathrm{SiC}$ composite powders as well.

Some main stepwise reactions in Reaction (3) are listed as follows [24-26]:

$$
\begin{gathered}
\mathrm{SiO}_{2}(\mathrm{~s})+\mathrm{C}(\mathrm{s})=\mathrm{SiO}(\mathrm{g})+\mathrm{CO}(\mathrm{g}) \\
\mathrm{SiO}(\mathrm{g})+3 \mathrm{CO}(\mathrm{g})=\mathrm{SiC}(\mathrm{s})+2 \mathrm{CO}_{2}(\mathrm{~g}) \\
\mathrm{SiO}(\mathrm{g})+2 \mathrm{C}(\mathrm{s})=\mathrm{SiC}(\mathrm{s})+\mathrm{CO}(\mathrm{g}) \\
\mathrm{C}(\mathrm{s})+\mathrm{O}_{2}(\mathrm{~g})=2 \mathrm{CO}(\mathrm{g})
\end{gathered}
$$

Reaction (8) is the main reaction for nucleation of $\mathrm{SiC}$ whiskers, while Reaction (9) is the main reaction for nucleation of $\mathrm{SiC}$ particles. The morphology of $\mathrm{SiC}$ whiskers was determined by two important processes: (1) When the concentrations of $\mathrm{SiO}$ and $\mathrm{CO}$ released from Reactions (7) and (10) reached an appropriate range, $\mathrm{SiC}$ began to nucleate as a stable phase to reduce the system energy [27,28]. Reaction (10) occurred at a relatively higher temperature than Reaction (7) [26]. (2) With the continual provision of $\mathrm{SiO}$ gas and $\mathrm{CO}$ gas, $\mathrm{SiC}$ whiskers grew longer through Reaction (8) along a certain direction due to the lowest surface energy of $\beta$-SiC. It was concluded that high reaction rates of Reactions (7) and (8) were essential to obtain SiC whiskers with high aspect ratio.

The reactivity of $\mathrm{SiO}_{2}, \mathrm{C}, \mathrm{SiO}$ gas, and $\mathrm{CO}$ gas were proportional to the reaction rate of Reactions (7) and (8). Based on the first-principles calculations, Wang [22] reported that the bond length in Si-O at the (101) plane of $\mathrm{SiO}_{2}$ became longer after adsorption of ferrous nanoparticles, indicating that iron could catalyze Reaction (7) by increasing the reactivity of $\mathrm{SiO}_{2}$. Wang [29] reported that the large distortion and strong interaction of nickel nanoparticles with $\mathrm{C}, \mathrm{SiO}$ gas, and $\mathrm{CO}$ gas could promote their dissociation of atomic bonds, further making them more reactive. This conclusion could also explain the catalytic effects of ferrous powders in this work. Hence, the reaction rates of Reactions (7) and (8) were both promoted by the ferrous catalyst. A greater ferrous catalyst amount provided more active sites. The negative slope of Reaction (3) in Figure 1 also meant that increasing heating temperature effectively improved the reaction rate. That is why the aspect ratio of SiC whiskers increased with increasing ferrous catalyst amount and heating temperature, as shown in Figure 6a-d. In addition, the reaction rate of Reaction (9) was also promoted by ferrous catalyst.

The formation process of $\beta$-SiC through Reaction (3) was completed at $1573 \mathrm{~K}$ for sample Z2, as shown in Figure 2, which was due to the combined effects of the ferrous catalyst and $\mathrm{NaCl}$ molten salt [30], as well as high activity of amorphous $\mathrm{SiO}_{2}$ decomposed from $\mathrm{ZrSiO}_{4}$. For Reactions (2) and (4), increasing the ferrous catalyst amount was helpful in dissociating atomic bonds in carbon black and the further accelerating formation of $\mathrm{ZrB}_{2}$ and $\mathrm{ZrC}$, as shown in Figure 3.

\subsection{Growth Mechanisms of SiC Whiskers in $\mathrm{ZrB}_{2}$-SiC Composite Powders}

The vapor-liquid-solid (VLS) mechanism was usually employed to explain the synthesis process of $\mathrm{SiC}$ whiskers with the addition of transition-metal catalysts [31,32]. The $\mathrm{SiO}$ gas and $\mathrm{CO}$ gas were absorbed into the catalyst droplet, and then $\mathrm{SiC}$ nucleated and grew along a direction on the interface between the nucleus and droplet. Lastly the catalyst droplets were left on the top of whiskers. However, there were no droplets found at the tips of whiskers in this work, suggesting that VLS growth mechanisms were not suitable to explain their growth behavior. Based on the XRD, SEM, EDS, TEM, HRTEM, and SAED analysis in Figures 2-6, a molten-salt-assisted iron-catalyzed vapor-solid (VS) mechanism is promoted in Figure 7 and described in detail as follows: 
(1) Preparation stage. At a low temperature, $\mathrm{B}_{2} \mathrm{O}_{3}$ and $\mathrm{NaCl}$ melted. They accelerated the decomposition of $\mathrm{ZrSiO}_{4}$ into $m-\mathrm{ZrO}_{2}$ and amorphous $\mathrm{SiO}_{2}$ by promoting the mass transfer of raw materials.

(2) Nucleation stage. Ferrous particles catalyzed Reactions (7) and (8) by increasing the reactivity of $\mathrm{SiO}_{2}, \mathrm{C}, \mathrm{SiO}$ gas, and $\mathrm{CO}$ gas, resulting in the nucleation of $\mathrm{SiC}$ whiskers at a certain temperature lower than $1573 \mathrm{~K}$. Meanwhile, carbon black with high reactivity was beneficial to the nucleation of $\mathrm{ZrB}_{2}$ grains through Reaction (2). The effect of $\mathrm{NaCl}$ molten salt was not evident here because the temperature approached its boiling point.

(3) Growth stage. SiC whiskers grew along $<111>$ on the solid surface of the $\mathrm{SiC}$ nucleus through Reaction (8) on the condition of appropriate heating temperature and ferrous catalyst amount. Some SiC nuclei which nucleated on the carbon black particles through Reaction (9) were more likely to grow into $\mathrm{SiC}$ nanoparticles. $\mathrm{ZrB}_{2}$ tabular grains continued to nucleate and grow.
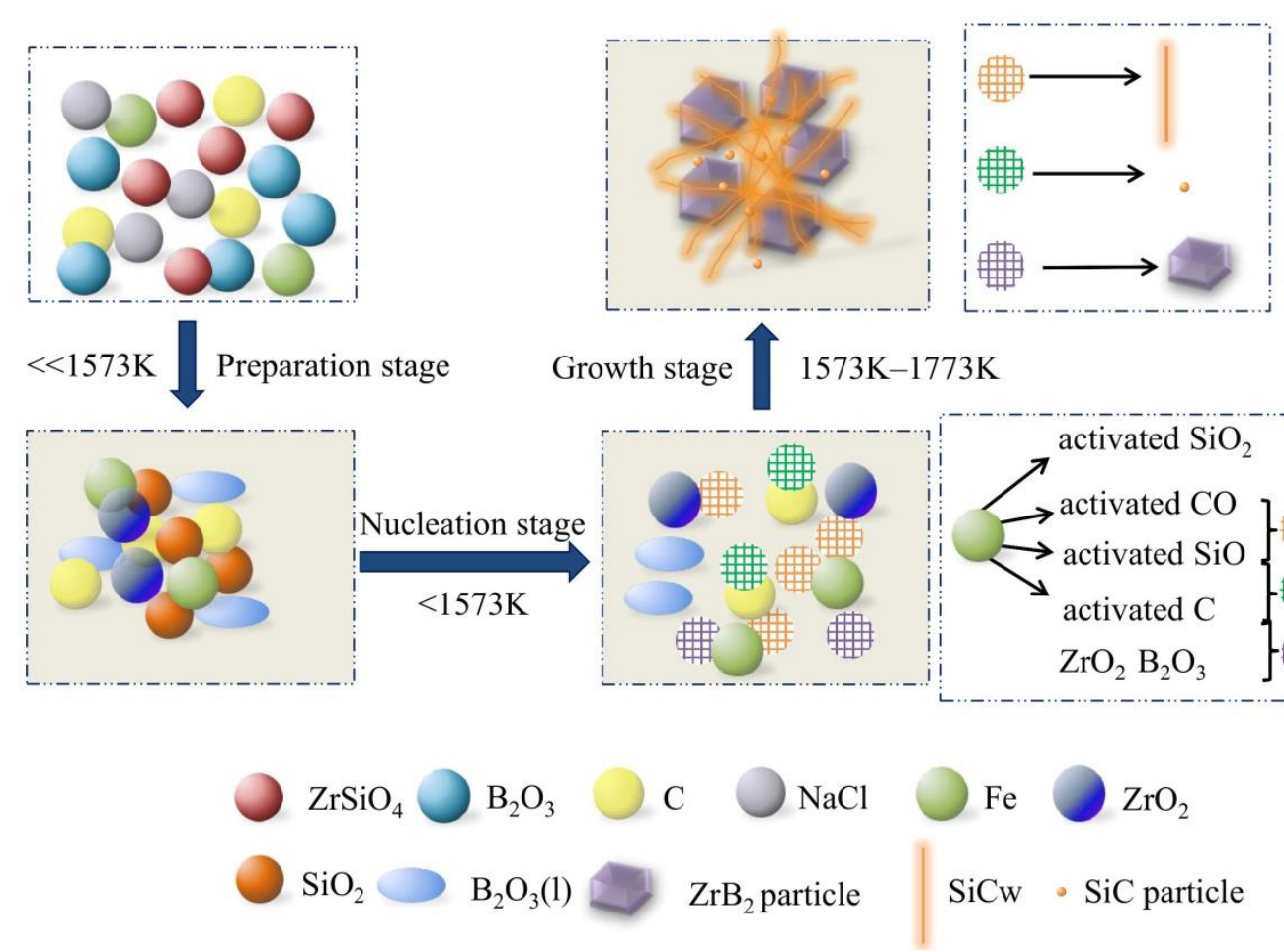

Figure 7. Illustrations of the possible growth process of $\mathrm{SiC}$ whiskers in the synthesis of $\mathrm{ZrB}_{2}-\mathrm{SiC}$ composite powders.

\section{Conclusions}

Phase-pure $\mathrm{ZrB}_{2}$-SiC composite powders with in situ grown $\mathrm{SiC}$ whiskers were successfully synthesized by molten-salt-assisted iron-catalyzed carbothermal reduction, which has great potential application in improving the fracture toughness of $\mathrm{ZrB}_{2}-\mathrm{SiC}$ composite ceramics. The in situ growth behavior of $\mathrm{SiC}$ whiskers was studied. Conclusions are summarized as follows:

(1) Phase-pure $\mathrm{ZrB}_{2}-\mathrm{SiC}$ composite powders were obtained when the molten ratio of raw materials was 0.2:0.5:1:1.5:8.4 (Fe: $\left.\mathrm{NaCl}: \mathrm{ZrSiO}_{4}: \mathrm{B}_{2} \mathrm{O}_{3}: \mathrm{C}\right)$ and the heating temperature was $1723 \mathrm{~K}$, in which $\beta$-SiC whiskers were single crystalline with a mean diameter of $0.15 \mu \mathrm{m}$ and aspect ratio of 70-120.

(2) Heating temperature and ferrous catalyst amount obviously influenced the phase composition and microstructure of $\mathrm{ZrB}_{2}-\mathrm{SiC}$ composite powders, especially for the morphology of $\mathrm{SiC}$ whiskers. With increasing heating temperature (1523-1723 K) and molar ratio of $\mathrm{Fe}$ to $\mathrm{ZrSiO}_{4}(0: 1$ to $0.2: 1)$, the aspect ratio of $\mathrm{SiC}$ whiskers increased significantly while the relative content of $\mathrm{SiC}$ phase 
changed little, and the relative content of $\mathrm{ZrB}_{2}$ phase increased continuously. Excess ferrous catalysts resulted in the formation of $\mathrm{ZrC}$ phase and serious grain agglomeration at $1723 \mathrm{~K}$.

(3) Molten-salt-assisted iron-catalyzed vapor-solid mechanism was promoted for the growth mechanism of in situ grown $\mathrm{SiC}$ whiskers in $\mathrm{ZrB}_{2}-\mathrm{SiC}$ composite powders. Ferrous catalysts played a major role in increasing the reactivity of $\mathrm{SiO}_{2}, \mathrm{C}, \mathrm{SiO}$ gas, and $\mathrm{CO}$ gas, further realized by the low temperature nucleation and high aspect ratio of $\mathrm{SiC}$ whiskers.

Excess carbon black in the ZrB2-SiC composite powders prepared by molten-salt-assisted iron-catalyzed carbothermal reduction method was difficult to remove, which calls for further studies to increase the purity of composite powders. The later work should focus on the following two points:

(1) Growth behavior of $\mathrm{ZrB}_{2}-\mathrm{SiC}$ composite powders with different molar ratios of $\mathrm{ZrO}_{2}$ to $\mathrm{SiO}_{2}$;

(2) Evaluation of toughening effects of in situ grown $\mathrm{SiC}$ whiskers on $\mathrm{ZrB}_{2}$-SiC composite ceramics, as well as the corresponding toughening mechanisms.

Author Contributions: All authors discussed and agreed upon the idea and made scientific contributions: writing-original draft preparation, X.L.; experiment design, X.L. and X.W.; experiment performance, X.L. and X.H.; data analysis, X.L. and L.D.; writing-review and editing, X.H. and L.D.; methodology and resources, X.W. All authors have read and agreed to the published version of the manuscript.

Funding: This research was funded by the Natural Science Foundation of Shaanxi Province for Youth (No. 2017JQ5100) and the Scientific Research Plan Projects of Shaanxi Education Department (No. 18JK0498).

Conflicts of Interest: The authors declare no conflict of interest.

\section{References}

1. Fahrenholtz, W.G.; Hilmas, G.E.; Talmy, I.G.; Zaykoski, J.A. Refractory diborides of zirconium and hafnium. J. Am. Ceram. Soc. 2007, 90, 1347-1364. [CrossRef]

2. Fahrenholtz, W.G.; Hilmas, G.E. Ultra-high temperature ceramics: Materials for extreme environments. Scr. Mater. 2017, 129, 94-99. [CrossRef]

3. Squire, T.H.; Marschall, J. Material property requirements for analysis and design of UHTC components in hypersonic applications. J. Eur. Ceram. Soc. 2010, 3, 2239-2251. [CrossRef]

4. Guo, S.Q. Densification of $\mathrm{ZrB}_{2}$-based composites and their mechanical and physical properties: A review. J. Eur. Ceram. Soc. 2009, 29, 995-1011. [CrossRef]

5. Silvestroni, L.; Sciti, D.; Melandri, C.; Guicciardi, S. Toughened ZrB ${ }_{2}$-based ceramics through SiC whisker or SiC chopped fiber additions. J. Eur. Ceram. Soc. 2010, 30, 2155-2164. [CrossRef]

6. Sciti, D.; Silvestroni, L. Processing, sintering and oxidation behavior of $\mathrm{SiC}$ fibers reinforced $\mathrm{ZrB}_{2}$ composites. J. Eur. Ceram. Soc. 2012, 32, 1933-1940. [CrossRef]

7. Bai, Y.H.; Sun, M.Y.; Li, M.X.; Fan, S.W.; Cheng, L.F. Improved fracture toughness of laminated ZrB $2-\mathrm{SiC}_{-}-\mathrm{MoSi}_{2}$ ceramics using $\mathrm{SiC}$ whisker. Ceram. Int. 2018, 44, 8890-8897. [CrossRef]

8. Zimmermann, J.W.; Hilmas, G.E.; Fahrenholtz, W.G.; Monteverde, F.; Bellosi, A. Fabrication and properties of reactively hot pressed $\mathrm{ZrB}_{2}-\mathrm{SiC}$ ceramics. J. Eur. Ceram. Soc. 2007, 27, 2729-2736. [CrossRef]

9. Du, S.; Cao, Y.N.; Zhang, Z.C.; Zhang, H.J.; Li, F.L.; Liu, L.L.; Zhang, S.W. Preparation of ZrB $2-S i C$ composite powders by carbothermal reduction of $\mathrm{ZrSiO}_{4}$. J. Chin. Ceram. Soc. 2014, 42, 779-784.

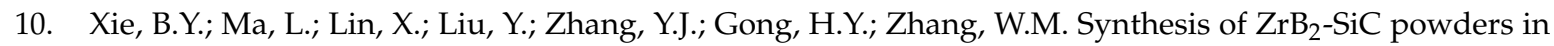
one-step reduction process. Ceram. Int. 2018, 44, 19522-19525. [CrossRef]

11. Li, F.L.; Tan, C.; Liu, J.H.; Wang, J.K.; Jia, Q.L.; Zhang, H.J. Low temperature synthesis of ZrB ${ }_{2}$-SiC powders by molten salt magnesiothermic reduction and their oxidation resistance. Ceram. Int. 2019, 45, 9611-9617. [CrossRef]

12. Cao, Y.N.; Zhang, H.J.; Li, F.L.; Lu, L.L.; Zhang, S.W. Preparation and characterization of ultrafine $\mathrm{ZrB}_{2}-\mathrm{SiC}$ composite powders by a combined sol-gel and microwave boro-carbothermal reduction method. Ceram. Int. 2015, 41, 7823-7829. [CrossRef]

13. He, J.B.; Gao, Y.; Wang, Y.G.; Fang, J.Y.; An, L.A. Synthesis of $\mathrm{ZrB}_{2}-\mathrm{SiC}$ nano-composite powder via polymeric precursor route. Ceram. Int. 2017, 43, 1602-1607. [CrossRef]

14. Ryu, H.Y.; Nersisyan, H.H.; Lee, J.H. Preparation of zirconium-based ceramic and composite fine-grained powders. Int. J. Refract. Met. Hard Mater. 2012, 30, 33-138. [CrossRef] 
15. Lin, Y.H.; Liu, J.H.; Song, S.L.; Liu, J.B.; Bashir, S.; Guo, Y.; Zhen, Q. Microstructure evolution and growth behavior of rod-shaped $\mathrm{ZrB}_{2}$ in situ preparation of $\mathrm{ZrB}_{2}-\mathrm{SiC}$ composite powders. Ceram. Int. 2019, 45, 4016-4021. [CrossRef]

16. Zhong, Z.X.; Yan, L.W.; Liu, L.; Xu, B.S. Fabrication of modified ultrahigh-temperature ceramic hybrid powders using in situ grown SiC nanowires. Ceram. Int. 2017, 43, 3462-3464. [CrossRef]

17. Zhang, J.; Li, W.; Jia, Q.L.; Lin, L.X.; Huang, J.T.; Zhang, S.W. Molten salt assisted synthesis of 3C-SiC nanowire and its photoluminescence properties. Ceram. Int. 2015, 41, 12614-12620. [CrossRef]

18. Prakash, J.; Venugopalan, R.; Tripathi, B.M.; Ghosh, S.K.; Chakravartty, J.K.; Tyagi, A.K. Chemistry of one dimensional silicon carbide materials: Principle, production, application and future prospects. Prog. Solid State Chem. 2015, 43, 98-122. [CrossRef]

19. Kaiser, A.; Lobert, M.; Telle, R. Thermal stability of zircon $\left(\mathrm{ZrSiO}_{4}\right)$. J. Eur. Ceram. Soc. 2008, 28, $2199-2211$. [CrossRef]

20. Krishnarao, R.V. Preparation of $\mathrm{ZrB}_{2}$ and $\mathrm{ZrB}_{2}-\mathrm{SiC}$ powders in a single step reduction of zircon $\left(\mathrm{ZrSiO}_{4}\right)$ with $\mathrm{B}_{4}$ C. Ceram. Int. 2017, 43, 1205-1209. [CrossRef]

21. Guo, C.C.; Cheng, L.F.; Ye, F.; Li, Z.C.; Xu, Z.S. Synthesis and characterization of carbon-poor SiC nanowires via vapor-liquid-solid growth mechanism. Ceram. Int. 2019, 45, 6440-6446. [CrossRef]

22. Wang, J.K.; Zhang, Y.Z.; Li, S.S.; Ge, S.T.; Song, J.B.; Zhang, H.I. Catalytic carbothermal reduction synthesis and mechanism of 3C-SiC from diatomite with Fe as catalyst. Chin. J. Mater. Res. 2018, 32, 767-774.

23. Khanr, A.K.; Pathak, L.C.; Godkhindi, M.M. Carbothermal synthesis of zirconium diboride $\left(\mathrm{ZrB}_{2}\right)$ whiskers. Adv. Appl. Ceram. 2007, 37, 155-160. [CrossRef]

24. Wang, J.G.; Huang, S.; Liu, S.; Qing, Z. EBSD characterization of the growth mechanism of SiC synthesized via direct microwave heating. Mater. Charact. 2016, 114, 54-61. [CrossRef]

25. Hu, P.; Pan, R.Q.; Dong, S.; Jin, K.F.; Zhang, X.H. Several millimeters long SiC-SiOx nanowires synthesized by carbon black and silica sol. Ceram. Int. 2016, 42, 3625-3630. [CrossRef]

26. Liu, C.Q.; Zhang, L.Y.; Li, X.; Chang, X.J.; Wu, Y.T.; Wang, X.F. Synthesis, characterization, and ceramization of a carbon-rich $\mathrm{SiCw}_{\mathrm{Z}} \mathrm{ZrC}-\mathrm{ZrB}_{2}$ preceramic polymer precursor. Ceram. Int. 2019, 45, 16097-16104. [CrossRef]

27. Hu, P.; Dong, S.; Zhang, D.Y.; Fang, C.; Zhang, X.H. Catalyst-assisted synthesis of core-shell $\mathrm{SiC} / \mathrm{SiO} 2$ nanowires via a simple method. Ceram. Int. 2016, 42, 1581-1587. [CrossRef]

28. Wang, D.; Xue, C.; Bai, H.; Jiang, N. Silicon carbide nanowires grown on graphene sheets. Ceram. Int. 2015, 41, 5473-5477. [CrossRef]

29. Wang, H.F.; Li, H.S.; Zhang, H.J.; Bi, Y.; Liu, J.H.; Zhang, S.W. Nickel-catalyzed preparation of self-bonded SiC refractories with improved microstructure and properties. J. Eur. Ceram. Soc. 2018, 38, 5219-5227. [CrossRef]

30. Mao, Y.B.; Park, T.J.; Zhang, F.; Zhou, H.J.; Wong, S.S. Environmentally friendly methodologies of nanostructure synthesis. Small 2007, 7, 1122-1139. [CrossRef]

31. Urretavizcaya, G.; López, P.J.M. Growth of SiC whiskers by VLS process. J. Mater. Res. 1994, 9, $2981-2986$. [CrossRef]

32. Li, X.; Zhang, G.Q.; Tronstad, R.; Ostrovskic, O. Synthesis of SiC whiskers by VLS and VS process. Ceram. Int. 2016, 42, 5668-5676. [CrossRef]

(C) 2020 by the authors. Licensee MDPI, Basel, Switzerland. This article is an open access article distributed under the terms and conditions of the Creative Commons Attribution (CC BY) license (http://creativecommons.org/licenses/by/4.0/). 